\title{
Penerapan Keselamatan Dan Kesehatan Kerja Pada Proses Perbaikan Kapal Kayu Di Daerah Pasir Panjang
}

\author{
Sapto Wiratno Satoto ${ }^{1}$, Hendra Saputra ${ }^{1}$, Nidia Yuninarsih ${ }^{1}$, Hanifah Widiastuti ${ }^{1}$, James Siregar ${ }^{1}$, Naufal \\ Abdurrahman Prasetyo ${ }^{1}$, Mufti Fathonah $\mathrm{M}^{1}$, Nurman $\mathrm{P}^{1}$, Sriyanto $^{1}$, Meida Perwira Antartika ${ }^{1}$, Yogantara ${ }^{1}$
}

${ }^{1}$ Polteknik Negeri Batam, Jl. Ahmad Yani, Tlk. Tering, Batam Kota, Kota Batam, Kepulauan Riau 29461, Indonesia

\begin{abstract}
Abstrak: Perbaikan dan perawatan kapal merupakan proses yang dilakukan pemilik kapal agar kondisi kapal yang digunakan selalu dalam kondisi prima. Masyarakat pesisir melakukan perbaikan kapal berdasar atas pengalaman yang biasanya diperoleh secara turun temurun. Dalam proses tersebut banyak masyarakat yang kurang peduli dengan resiko keselamatan dan kesehatan kerja. Hal ini bisa terjadi karena msyarakat sering berfikir bahwa selama ini kegiatan tersebut tidak menjadi permasalahan sebab mereka tidak pernah sakit. Dengan kurang awamnya masyarakat terhadap masalah tersebut maka perlu diberikan sebuah penyuluhan serta langkah aman dalam melakukan perbaikan kapal yang pasti akan mereka lakukan.
\end{abstract}

Kata Kunci: Perbaikan kapal, keselamatan dan kesehatan kerja, pesisir

\begin{abstract}
Ship repair and maintenance is a process carried out by ship owners so that the condition of the vessel always in prime condition. Coastal communities make ship repairs based on experiences that are usually obtained from generation to generation. In this process, many people are less concerned with the risks of occupational safety and health. This can happen because people often think that these activities have not become a problem because they have never been sick. With the lack of public awareness of the problem, it is necessary to provide an extension and safe steps in carrying out ship repairs that they will definitely do.
\end{abstract}

Keywords: Ship repair, occupational safety and health, coastal

\section{PENDAHULUAN}

Seringnya masyarakat melakukan perbaikan kapal tanpa memperhatikan aspek keselamatan menjadikan proses perbaikan kapal menjadi aktifitas keseharian yang berpotensi menimbulkan bahaya[1]. Potensi tersebut menjadi kelihatan kecil disebabkan karena belum adanya kejadian yang terjadi dalam waktu yang singkat dan cepat. Proses perbaikan yang dilakukan oleh nelayan rata-rata menggunakan bahan kimia, 
bahan berbau tajam, alat-alat listrik dan cairan yang tidak baik jika terhirup masuk ke paru-paru dalam jangka waktu yang lama. Penggunaan peralatan perbaikan kapal menjadi potensi bahaya yang tidak disadari namun jika dilakukan secara terus menerus maka dampaknya akan muncul beberapa tahun kemudian.

\section{TINJAUAN PUSTAKA}

Perahu kayu saat ini masih banyak digunakan walaupun sudah mulai tergeser dengan perahu fiber walaupun pergeseran itu tidak secara total. Bahan perahu kayu dipercayai mempunyai kelebihan yang tidak dapat diganti oleh bahan yang lain, maka saat ini kombinasi metode yang digunakan pada pembuatan kapal fiber dan kayu dipadukan[2]. Langkah yang dilakukan yaitu dengan kombinasi pengunaan epoxy pada pembuatan perahu kayu. Selain karena massih percaya bahwa kayu tidak dapat digantikan, para nelayan masih mempertahankan perahu kayu dimungkinkan dengan berbagai alasan, antara lain: waktu dan sumber daya pembuatan kapal, nilai sejarah dan kondisi perahu yang dianggap mampu lebih baik dari bahan lain. Dengan alasan dasar itu, para nelayan lebih memilih bertahan dengan perahu kayu namun dengan resiko harus melakukan perbaikan ataupun pemerliharaan lebih baik agar kapal bisa bertahan lebih lama.

Kerusakan yang terjadi pada perahu kayu lebih banyak diakibatkan usia kayu. Secara alami kayu akan kehilangkan kekakuannya sehingga kekuatan kayu akan menurun. Biasanya yang paling cepat mengalami adalah bagian lambung perahu karena sering dihantam gelombang sehingga mengalami kelelahan terlebih dahulu.

Pelapukan adalah salah satu kerusakan pada perahu dengan bahan kayu sehingga perahu kayu dipastikan akan sering mengalami hal ini. Ini terjadi dikarenakan oleh jamur yang hidup di selulosa kayu. Perlu diperhatikan agar jamur tidak hidup di perahu karena jamur dapat hidup dengan subur dengan kondisi jika ada makanan (dari selulosa kayu, moisture, oxygen, kondisi suhu ideal $24-30^{\circ} \mathrm{C}$ ).

Pada pemeliharan dan perbaikan perahu kayu diperlukan langkah-langkah yang sistematis agar sasaran pemeliharan dan perbaikan dapat terjadi dengan baik. Pertama adalah melakukan inspeksi agar diketahui struktur dari perahu tersebut. Kemudian dilakukan lokalisasi area yang mengalami kerusakan. Setelah itu lakukan langkah perbaikan pada daerah yang mengalami kerusakan terutama pada bagian yang mengalami pelapukan. Buang kayu yang mengalami pelapukan sehingga tertinggal bagian yang keras saja. Gunakan pahat kayu manual seperti pada gambar 1. 


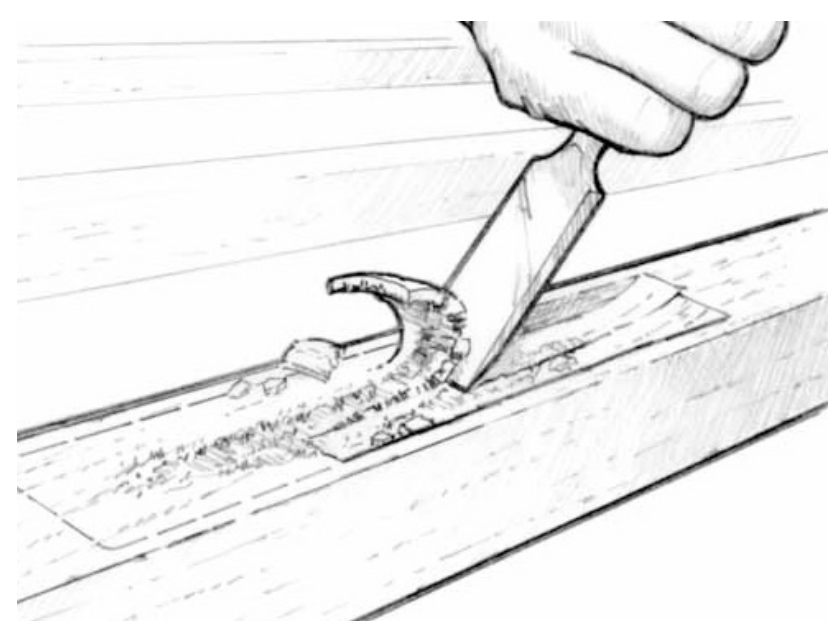

Gambar 1 Memahat Bagian Yang Lapuk

Pemahatan kayu yang digambarkan pada gambar 1 bertujuan untuk menghilagkan serta membersihkan bagian kayu yang mengalami kerusakan. Jika proses pemahatan bagian yang lapuk sudah selesai, isi bagian yang kosong tersebut dengan epoxy atau perekat kayu. Setelah itu tempelkan dengan potongan kayu yang dibentuk seperti potongan yang hilang. Seperti digambarkan pada gambar 2. Dan gambar 3 .

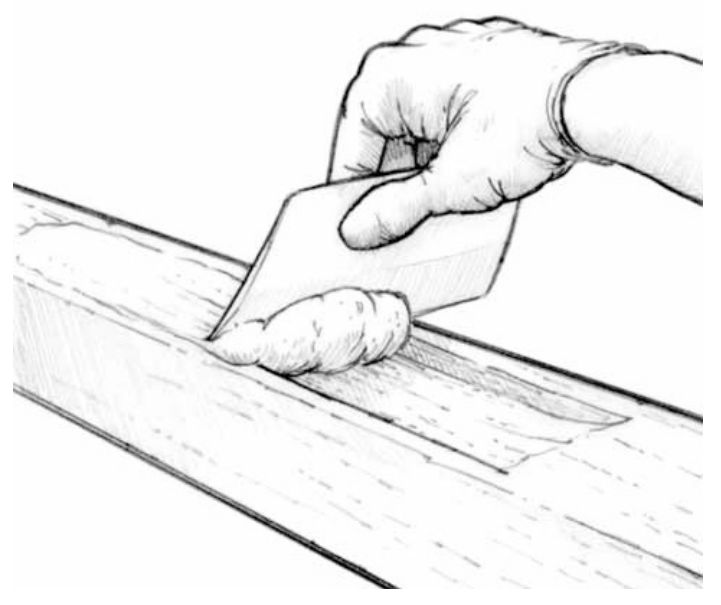

Gambar 2 Mengisi Dengan Perekat 


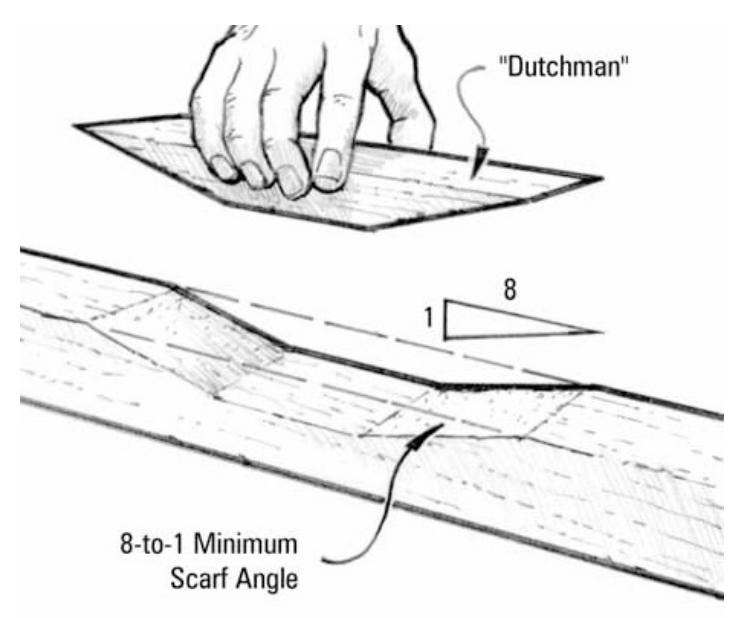

Gambar 3 Menempelkan Kayu

Dari gambar disebut dapat diketahui bahwa proses pengeleman memegang peranan yang penting. Dengan pentingnya setiap proses yang dilakukan sehingga setiap langkah yang dilakukan perlu dilakukan dengan hati-hati.

Pada rangka yang lapuk dan lapuknya kecil-kecil dilakukan pengeboran yang kemudian diisi dengan bahan epoxy. Lubang yang dibuat bersudut 45 derajat dan pada saat pengisian dipastikan dalam kondisi kering. Lubang bor sekitar 3/16 inchi dengan jarak antar lobang sekitar 1 inchi. Dengan cara menginjeksi lubang yang telah dibuat seperti pada gambar 4 dan 5 .

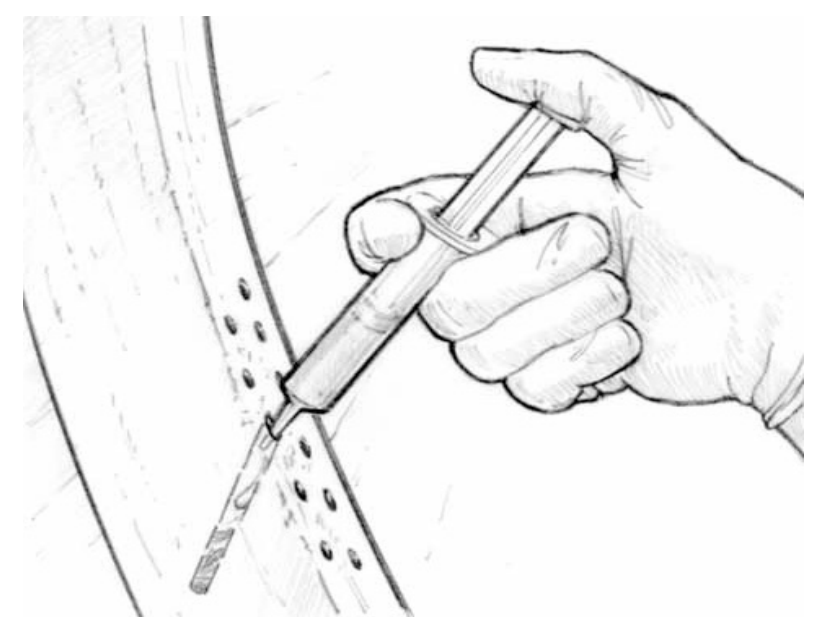

Gambar 4 Injeksi Perekat Pada Lubang Rangka 


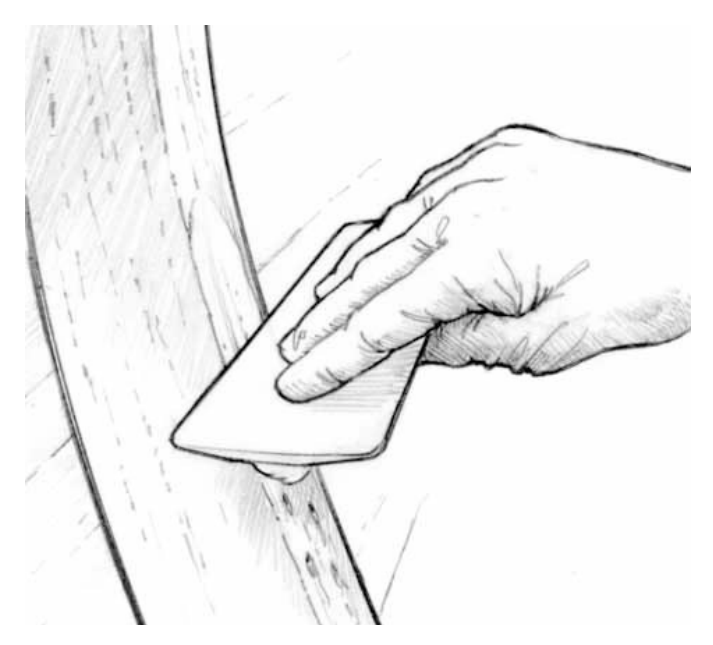

\section{Gambar 5 Di Rapikan dan Ditutup Semua Permukaan Sehingga Tidak Ada Udara Masuk}

Lubang-lubang yang muncul seperti pada gambar di atas perlu menjadi perhatian agar tidak menjadi tempat bagi tumbuhan ata hewan yang dapat merusak kayu. Hewan dan tumbuhan yang tumbuh pada bagian yang berlubang tersebut kemungkinan akan sulit utuk dikeluarkan karena benuk lubang yang kecil. Proses di atas merupakan teknik dasar dalam perbaikan pada bodi perahu kayu. Perbaikan pada rangka akan sama namun proses pemotongan dan penyambungan akan terjadi dalam sekala yang lebih besar. Jurnal yang membahas bagaimana nelayan Kepri melakukan perbaikan perahu kayu pernah disampaikan oleh Mufti F.M et. al, 2014[3]. Jurnal tersebut membahas proses pembangunan kapal tradisional. Proses yang dilakukan masih menggunakan cara tradisional yaitu dengan menggunakan kemampuan yang didapat secara turun temurun dimana proses pembangunan juga jauh dari penggunaan teknologi.

Dalam proses perbaikan kapal, banyak nelayan tradisional menggunakan bahan fiberglass sebagai bahan dan alat untuk melakukan perbaikan. Penggunaan ini dikarenakan bahan ini mudah dan cepat untuk diaplikasikan dalam proses perbaikan kapal. Salah satu bahan yang digunakan adalah serat kaca. Serat kaca tersebut terdiri dari berbagai macam ukuran. Ukuran serat kaca tersebut beraneka ragam, ada yang bisa dilihat dengan mata telanjang, ada juga yang tidak tampak. Yang berbahaya adalah apabila partikel tersebut masuk ke dalam hidung, tenggorokan serta mengenai kulit dari pekerja.

Kontak dengan barang tersebut jika terjadi dalam waktu yang lama akan menyebabkan terjadinya efek yang berkepanjangan. Manusia kadang tidak tahu bahwa tubuhnya telah terkontaminasi dengan bahan tersebut. Hal ini disebabkan karena dampak tersebut bisa muncul cepat atau lambat tergantung dari kemampuan masing-masing tubuh manusia. Selain dari dampak bahan fiberglass[4] yang berbentuk serat kaca tersebut, dampak buruk dari proses pembuatan fiberglass tersebut juga dapat berasal dari cairan yang digunakan (resin, katalis) yang jika pengunaannya tidak hati-hati dapat menyebabkan iritasi.

Langkah-langkah perlindungan yang dapat digunakan anatara lain 
a. Memberikan ventilasi dan lingkungan kerja yang memudahkan udara dapat berganti dengan mudah.

b. Berhati-hati ketika membersihkan debu yang merupakan satu langkah untuk memberikan perlindungan bagi tubuh sebab bisa jadi debu yang berterbangan tersebut mengandung serat kaca yang berbahaya bagi tubuh

c. Menggunakan pakaian pelindung baik pelindung tangan, hidung dan kacamata. Hal ini bertujuan untuk mengurangi adanya kontak dengan cairan tersebut secara langsung

d. Kebiasaan untuk mencuci tangan sebelum makan setalah beraktifitas dengan proses perbaikan kapal sehingga dapat mengurangi masuknya material tersebut ke dalam tubuh manusia.

Dalam proses perawatan dan perbaikan kapal, terdapat beberapa metode atau langkah yang berbeda dalam pelaksanaannya. Perbedaan tersebut dapat disebutkan sebagai berikut:

- Perawatan

Perawatan adalah proses, cara, perbuatan merawat, pemeliharaan, penyelenggaraan. Dalam hal ini perawatan yang dilakukan utuk kapal tradisional adalah:

- Menghilangkan lumut

- Menghilangkan hewan laut

- Pendempulan

- Pengecatan dsb

- Perbaikan

Perbaikan adalah hasil, perbuatan, usaha, dan sebagainya untuk memperbaiki atau membuat sesuatu menjadi baik. Perbaikan yang dilakukan pada kapal traidisional antara lain:

- Perbaikan lambung kapal yang bocor

- Penggantian bagian rangka yang patah

Dalam proses perbaikan tersebut terdapat beberapa langkah yang dilakukan mulai proses pembersihan, penyekrapan, pelapisan sampai dengan pengecatan ulang[5]. Proses yang dilakukan bisa dilakukan dalam ruangan tertutup maupun terbuka disesuaikan dengan kondisi pada saat perawatan dan perbaikan kapal. Gambar 6 berikut ini merupakan gambaran prosesperbaikan kapal. 


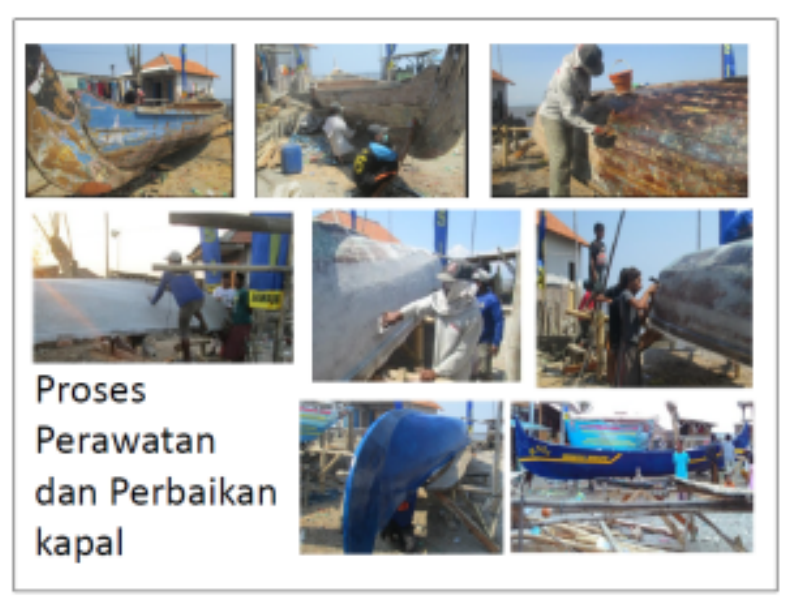

Gambar 6 Proses Reparasi Kapal

Pada gambar 6 tersebut, proses diawali dari kapal yang terparkir di bibir panti yang kemudian dilakuka proses penyekrapan. Proses tersebut dilakukan secara menyeluruh baik pada bagian atas maupun pada bagian bawah dari kapal. Di dalam gambar terlihat juga bahwa pengerjaan dilakukan oleh banyak orang untuk mempercepat proses pengerjaan. Dan biasanya nelayan melakukan ini secara bergantian pada kapal kayu mereka untuk mempermudah dan mempercepat proses perbaikan. Setelah proses yang dilakukan selesai, maka langkah berikutya adalah membawa kapal tersebut kembali ke pantai.

Dalam proses reparasi dan perbaikan terdapat beberapa material yang digunakan. Material-material tersebut umumnya terkait dengan material komposit. Material tersebut diharapkan akan dapat meperkuat material asli kapal kayu. Material tersebut antara lain[6]:

a. Resin

- Bahan utama dalam pembuatan aneka barang fiberglass yang pertama yaitu resin. Ada beberapa kegunaan dari resin yaitu untuk hiasan, lem, bahan hardware pengganti plastik atau kaca, mika dan lainnya. Bentuk resin seperti cairan kental, bening sedikit berwarna merah atau hijau. Resin mempunyai beberapa tipe dari yang keruh, berwarna hingga yang bening.

b. Katalis

- Katalis merupakan bahan aktif yang digunakan untuk mempercepat reaksi pengerasan resin, dan dapat membuat fiberglass bening dan berfungsi untuk pengencer adonan. Jika penggunaan katalis yang sedikit maka akan membuat resin mengeras dalam waktu yang lama. Sementara jika Anda menggunakan katalis yang terlalu banyak maka akan mempercepat pengerasan resin. Oleh karena itu harus bisa dipastikan takaran pada komponen tersebut dengan tepat.

c. Pewarna 
- Pigment adalah zat pewarna saat bahan fiberglass dicampur. Pemilihan warna disesuaikan dengan selera pembuatnya. Pada umumnya pemilihan warna untuk mempermudah proses akhir saat pengecatan.

d. Serat Fiber / Mat

- Mat adalah bahan pembuat fiberglass yang berupa anyaman mirip kain dan terdiri berdasarkan beberapa contoh, dad contoh anyaman halus sampai dengan anyaman yang kasar atau akbar dan sporadis-jarang.

Gambar 7 berikut menunjukkan gambar material fiber

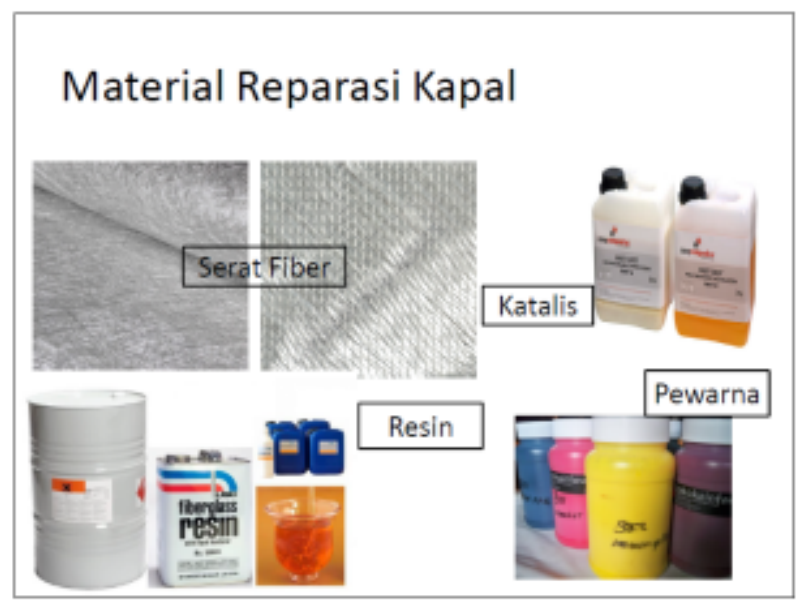

Gambar 7. Gambar Material Fiberglass

Keterangan pada gambar di atas tertulis pada foto yang antara lain sehingga dapat dilihat bentuk dri material yang dijelaskan di atas.

Dalam proses perbaikan kapal dengan menggunakan material komposit tersebut, terdapat resiko yang ditimbulkan oleh penggunaan material komposit. Dampak penggunaan dari material tersebut dapat dijelasakan dalam gambar 8 berikut: 

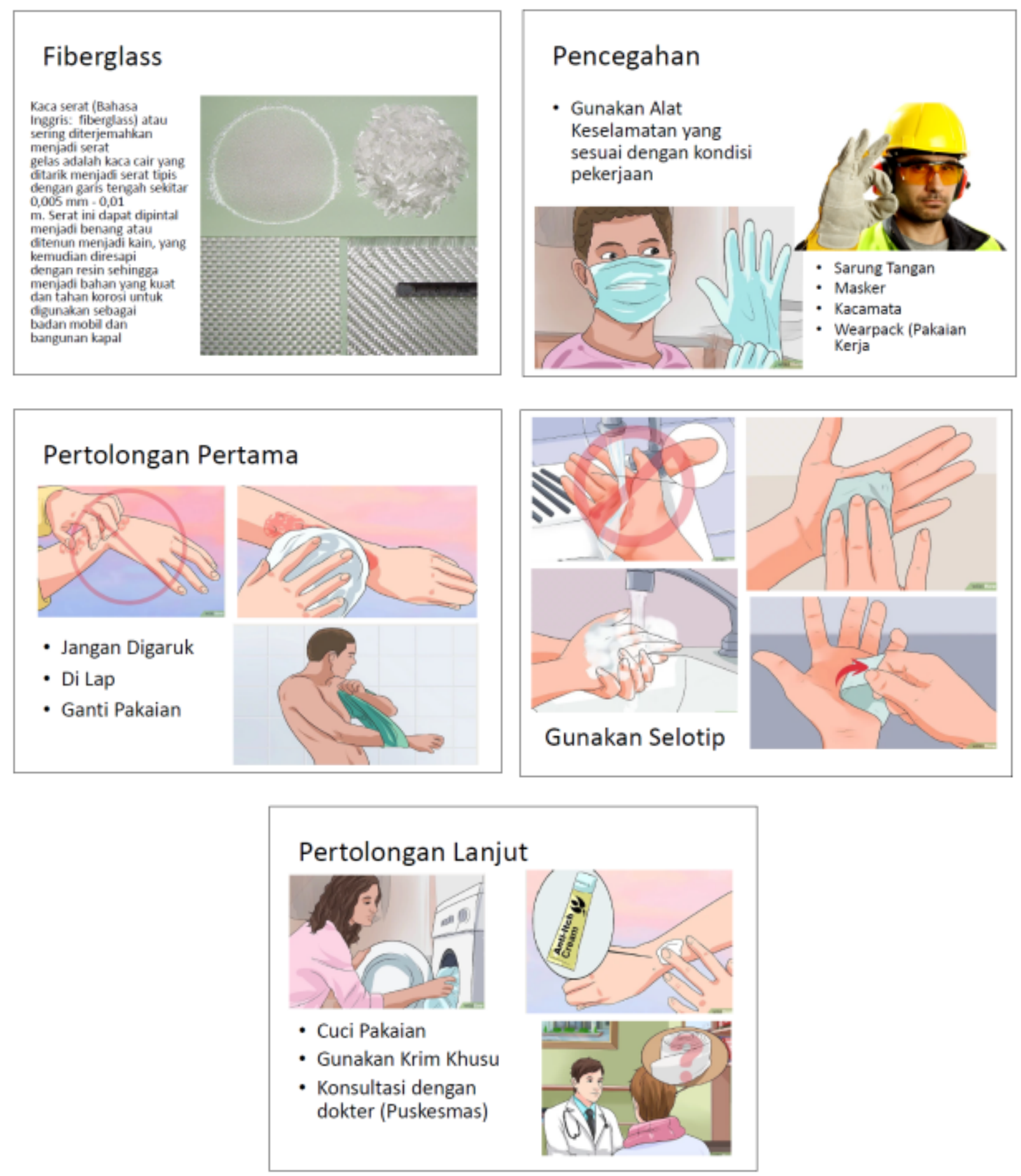

Gambar 8. Langkah-langkah Mencegah Dampak Buruk Fiberglass

Pada gambar 8 tersebut terdapa metode serta langkah-langkah yang bisa dilakukan untuk mencegah dampak dari fiberglass. Selain yang ditimbulkan dari bahan dan material komposit, faktor bahaya yang mungkin timbul dari proses perbaikan dan perawatan kapal adalah dehidrasi. Resiko ini semakin sering muncul ketika proses perawatan dan perbaikan kapal dilakukan di tempat terbuka. Selain itu resiko lain 
yang mungkin timbul adalah terjadinya dehidrasi dimana ciri-ciri dan penanganannya dapat diliat dari gambar 9 berikut:
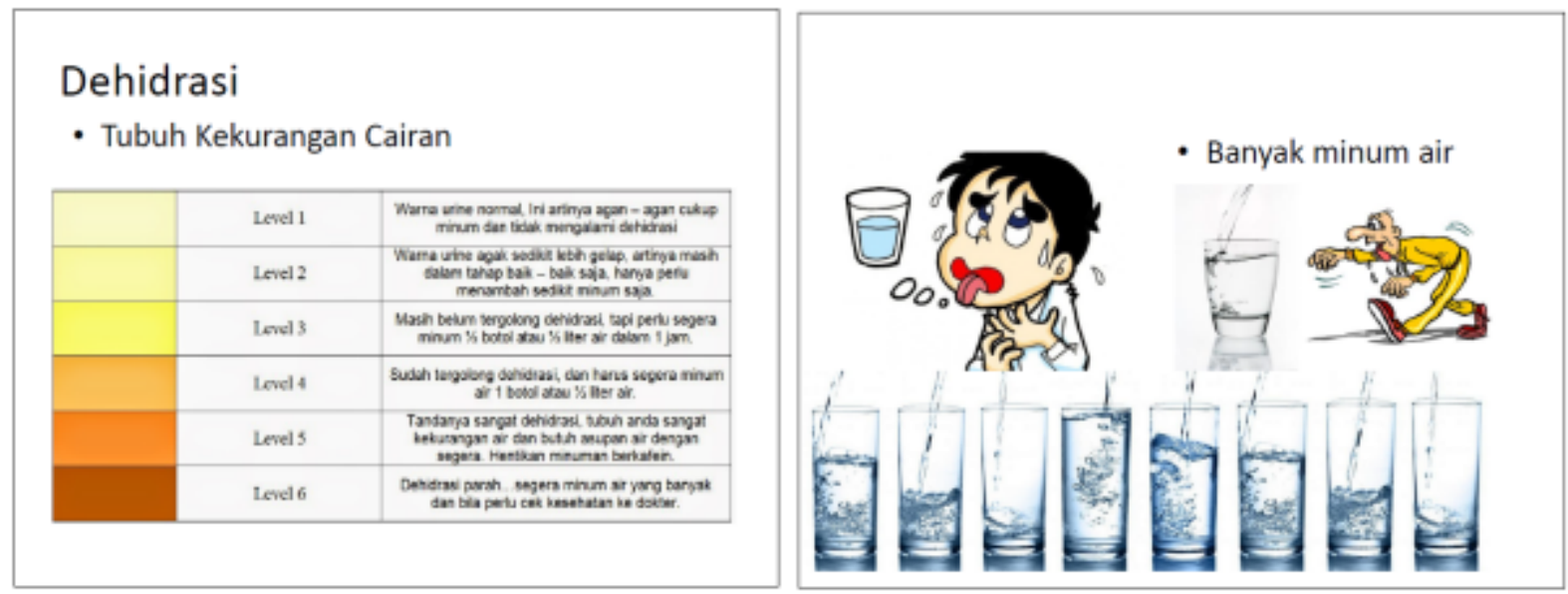

Gambar 9. Ciri-ciri Dehidrasi dan Pencegahannya

Proses perbaikan kapal menghasilkan material sisa yang jika tidak dilakukan penanganan akan membawa dampak buruk bagi kesehatan masyarakat. Dampak buruk material sisa tidak dapat dihindari ketika bekerja dalam bidang perbaikan dan perawatan. Untuk mengatasi permasalah tersebut maka diperlukan penanganan yang lebih lanjut. Proses penangan limbah dapat dilakukan dengan proses yang dapat diliat pada gabar 10 berikut
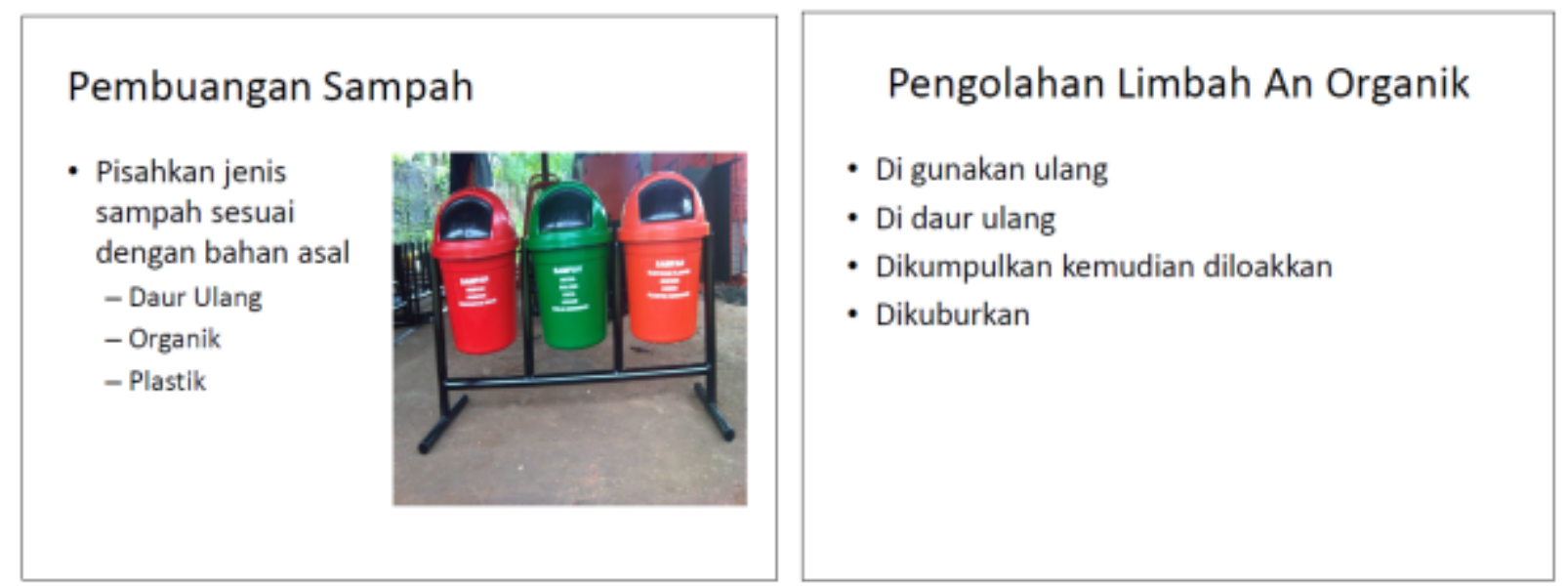

Gambar 10. Proses Penanganan Limbah Sampah

Gambar 10 tersebut menjelaskan prosespenangan limbah berupa car pembuangan dan pegolahan limbah. Proses penangan dilakukan agar limbah yang dihasilkan tidak menjadi sumber bahaya bagi masyarakat di sekitar pekerja serta pekerja itu sendiri. Dngan penanganan yang baik maka resiko serta bahaya yangtimbul dapat diminimalisir dan proses pengerjaan dapat berlangsung aman dan nyaman. 


\section{METODE PELAKSANAAN}

\section{Konsep Kegiatan}

Kegiatan ini akan dilakukan dalam bentuk penyuluhan serta praktek penggunaan alat-alat keselamatan serta kesehatan kerja. Penyuluhan dilakukan dengan memberikan pengetahuan kepada warga dengan cara dijelaskan serta diberikan gambar dan dibawakan juga beberapa sample mengenai bahan-bahan yang berbahaya. Tujuan dari penjelasan tersebut adalah agar masyarakat lebih memahami penjelasan dengan mudah. Setelah dilakukan penjelasan mengenai bahan-bahan yang berbahaya, kemudian dilakukan praktek penggunaan alat-alt keselamatan. Alatalat keselamatan yang diprakekkan antara lain penggunaan kacaata, penggunaan helm, penggunaan rompi, penggunaan pelampung, serta penggunaan sarung tangan pada proses perbaikan kapal.

Kegiatan direncanakan akan berlangsung dengan melibatkan beberapa pimpinan kelompok nelayan. Tujuannya adalah agar informasi tersebut dapat tersebar kepada nelayan-nelayan lain sebingga dapat menyebarkanefek positif kepada masyarakat.

\section{Lokasi dan Sasaran Kegiatan}

Lokasi kegiatan ini dilakukan di desa pasir panjang rempang cate, Galang, Kepualauan Riau. Kegiatan ini ditujukan untuk masyarakat yang bekerja di sebagai nelayan dimana kegiatan ini akan dilaksanakan selama 1 hari dalam bentuk presentasi, pemaparan dan praktikum.

\section{Metode Kegiatan}

Metode kegiatan dilakukan dengan proses berikut:
a. Pemaparan atau presentasi
b. Praktikum penggunaan alat
c. Pengenalan alat-alat yang berbahaya

\section{HASIL DAN PEMBAHASAN}

Kegiatan telah terlaksana pada 22 Sepetember 2018, yang dihadiri oleh seluruh anggota team serta dilakukan bersamaan dengan kegiatan lain. Dalam kegiatan tersebut kegiatan dilakukan sesuai dengan rencana yang telah disusun bersama. Dalam kegiatan tersebut dilakukan penyuluhan kepada warga terkait dengan proses perawatan dan perbaikan kapal serta dampak yang mungkin timbul ketika proses perawatan dan perbaikan kapal. Proses penyuluhan dan praktek tersebut dapat dilihat ada gambar 11 berikut: 

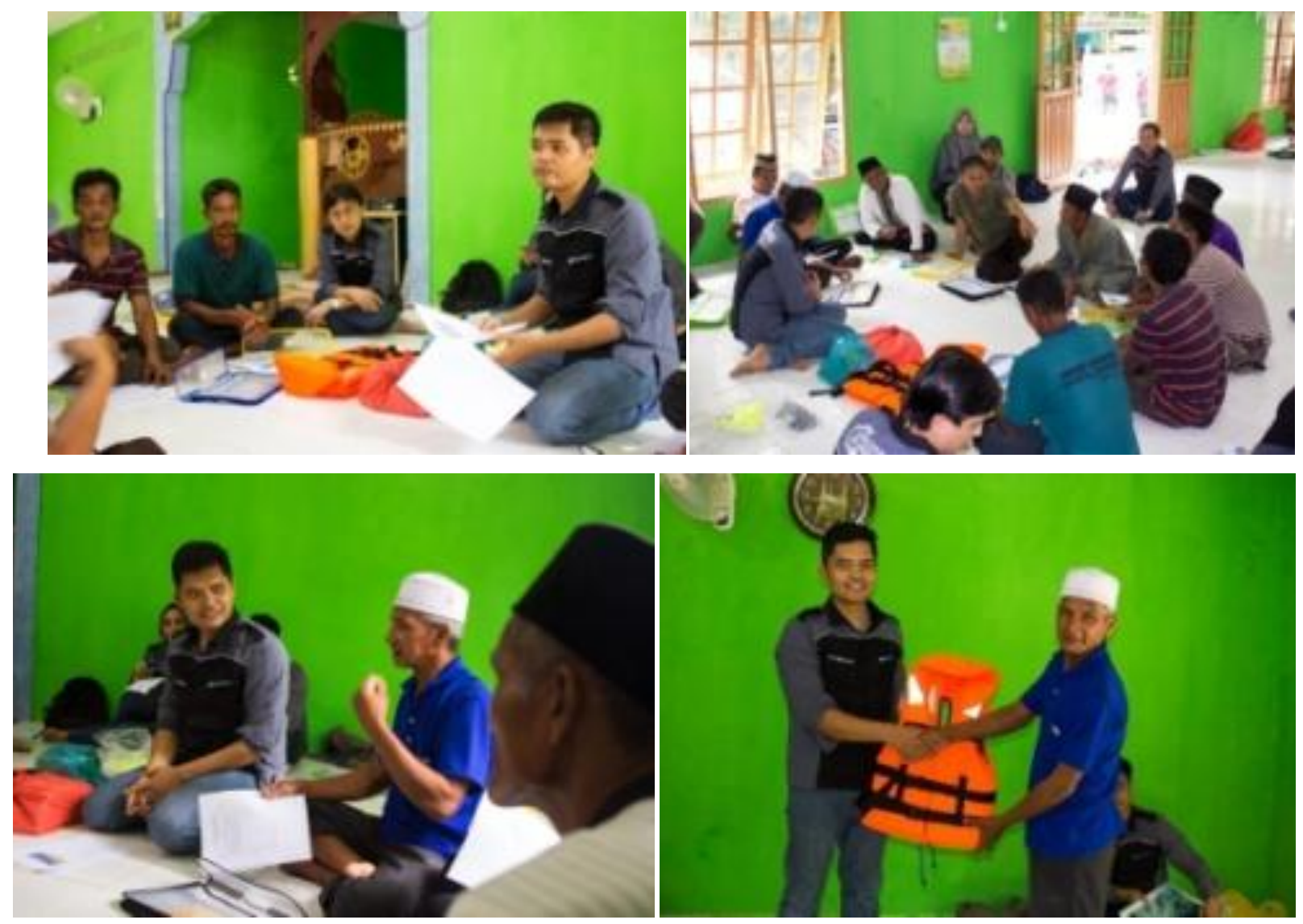

Gambar 11 Kegiatan Penyuluhan dan Diskusi

Dalam kegiatan yang tergambar pada gambar 11 tersebut diserahkan bantuan kepada warga sekitar berupa alat keselamatan sehingga dapat ditunjukkan kepada masyarakat beberapa alat keselamatan yang seharusnya mereka pakai namun selama ini diabaikan. Dengan diberikan bantuan tersebut diharapkan mampu mendorong masyarakat untuk melakukan kegiatan dilakukan dengan aman serta dengan peralatan yang mumpuni. Antusiasme masyarakat dalam kegiatan tersebut cukup besar dilihat dari banyaknya masyarakat yang datang serta dilihat juga dari adanya harapan dan keinginan masyarakat agar Politeknik Negeri Batam melaksanakan kegiatan pengabdian tersebut secara berkesinambungan sehingga masyarakat dapat mengambil manfaat dari kegiatan tersebut. Kemudian Politeknik Negeri Batam juga memiliki wadah untuk mengaplikasikan serta menerapkan ilmu pengetahuan dilingkungan masyarakat sehingga ilmu yang diperoleh, dipelajari dan dikembangkan lebih bermanfaat bagi kehidupan bermasyarakat, berbangsa dan bernegara di pulau terluar di Indonesia.

Setelah dilakukan prose penyuluhan dan diskusi tersebut, dilakukan juga pengambilan foto bersama yang terdapt pada gambar 12 berikut. 

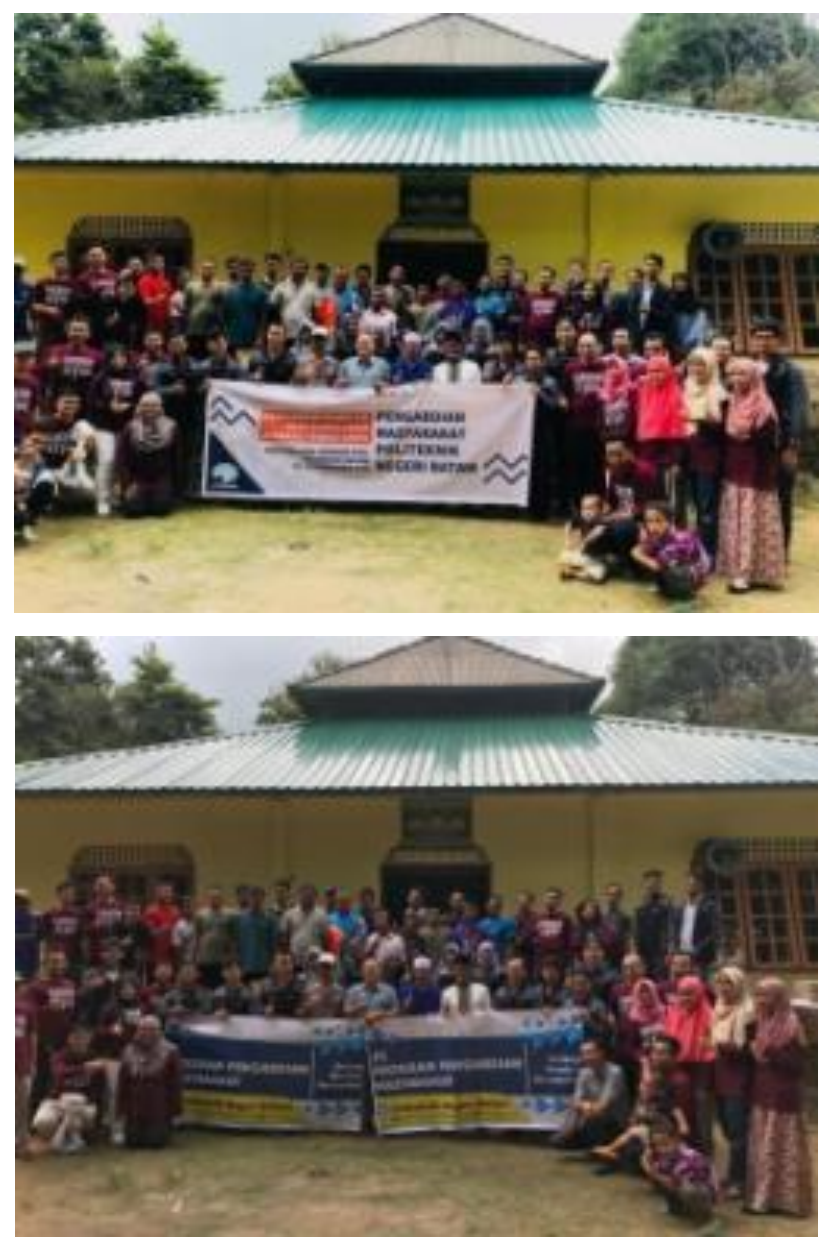

Gambar 12 Foto bersama dengan Team Lain

Gambar 12 merupakan gambar yang diambil bersama dengan anggota team yang juga mengadakan kegiatan. Dari gambar 12 tersebut dapat dilihat antusiasme warga sekitar pada kegiatan pengabdian masyarakat.

\section{DISKUSI}

Dalam kegiatan yang dilakukan, hal yang dilakukan adalah melakukan penyuluhan serta melakukan diskusi terkait dengan kebutuhan warga sekitar yang berhubungan dengan keselamatan serta berhubungan dengan kegiatan nelayan dalam bekerja di lautan. Dalam diskusi beikut di dapatkan data sebagai berikut[7]: 


\section{QUESSIONER PENGABDIAN MASYARAKAT \\ POLITEKNIK NEGERI BATAM \\ 2018}

\section{Kegiatan:}

\begin{tabular}{|c|l|c|c|c|c|c|}
\hline \multirow{2}{*}{ No } & \multicolumn{1}{|c|}{ Deskripsi } & \multicolumn{1}{|c|}{ Skala } \\
\cline { 3 - 6 } & & $\mathbf{1}$ & $\mathbf{2}$ & $\mathbf{3}$ & $\mathbf{4}$ & $\mathbf{5}$ \\
\hline 1 & Apakah kegiatan ini bermanfaat bagi anda? & & & & 9 \\
\hline 2 & Apakah kegiatan ini bisa menambah pengetahuan anda? & & & & 9 \\
\hline 3 & $\begin{array}{l}\text { Apakah dengan kegiatan ini anda mengetahui pentingnya } \\
\text { keselamatan dan kesehatan dalam melakukan aktifitas perbaikan } \\
\text { kapal? }\end{array}$ & & & 1 & 8 \\
\hline 4 & $\begin{array}{l}\text { Apakah dengan kegiatan ini anda memiliki ide terkait dengan } \\
\text { keselamatn dan kesehatan kerja? }\end{array}$ & 1 & & & & 7 \\
\hline 5 & Apakah perlu diadakan kegiatan seperti ini secara periodik? & & & & & \\
\hline
\end{tabular}

Jelaskan dan tuliskan pendapat anda yang belum tercantum dalam pernyataan di atas:

- Perlu pelatihan terkait engan fiber glass

\section{Penyaji}

\begin{tabular}{|c|c|c|c|c|c|c|}
\hline \multirow{2}{*}{ No } & \multirow{2}{*}{ Deskripsi } & \multicolumn{5}{|c|}{ Skala } \\
\hline & & 1 & 2 & 3 & 4 & 5 \\
\hline 1 & Apakah penyaji menyampaikan materi dengan baik? & & & & & 8 \\
\hline 2 & Apakah penyaji mampu menguasai materi dengan baik & 1 & & & 3 & 4 \\
\hline 3 & $\begin{array}{l}\text { Apakah penyaji mampu menyelesaikan dan menjawab } \\
\text { pernyataann dengan baik? }\end{array}$ & 1 & & & & \\
\hline 4 & $\begin{array}{l}\text { Apakah penyaji mampu memotivasi mengenai terkait } \\
\text { keselamatan kerja? }\end{array}$ & 1 & & & & 7 \\
\hline 5 & $\begin{array}{l}\text { Apakah penyaji memberikan pandangan baru mengenai } \\
\text { keselamatan dan kesehatan kerja? }\end{array}$ & & 3 & & & 3 \\
\hline
\end{tabular}

Jelaskan dan tuliskan pendapat anda yang belum tercantum dalam pernyataan di atas:

- Perlu bantuan mengenai pengadaan alat tangkap ikan 
Dari data tersebut di dapatkan bahwa ternyata warga sangat terbuka menyambut kegiatan ini. Dilihat dari partipasi warga untuk mengikuti kegiatan ini sampai dengan selesai serta memberikan masukan dan saran untuk kegiatan ini. Dari masukan yang dsampaikan ternyata ada beberapa masukan juga yang didapatkan anatara lain:

$\checkmark$ Terkait dengan pengabdian selanjutnya masyarakat memerlukan penjelasan terkait dengan pembuatan campuran bahan fiberglass

$\checkmark$ Disampaikan juga bahwa masyarakat sangat membutuhkan bantuan terkait dengan alat tangkap yang mereka butuhkan untuk menangkap ikan di laut. Selama ini mereka kurang mampu untuk membeli alat tersebut sebab alat tersebut mahal sedangkan penghasilan nelayan dari menjual ikan tidak begitu banyak.

\section{KESIMPULAN}

Kesimpulan dari laporan ini antara lain:

- Pengabdian masyarakat berjalan lancar dan sesuai dengan yang udah direncanakan

- Perlunya diadakan pengabdian lanjutan untuk tahun depan terkait dengan komposisi fiberglass yang tepat untuk nelayan serta proses pengecatan

Untuk kedepannya diharapkan kegiatan yang direncanakan dengan masyarakat dapat dilaksanakan dengan baik sehingga masyarakat dapat mengambil ilmu serta mengaplikasiskan dalam kehidupan nelayan sebgai obyek pengadian.

\section{UCAPAN TERIMA KASIH}

Terimakasih yang sebesar-besarnya kami acapkan kepada Allah SWT atas limpahan rahmatnya keguatan ini dapat terlaksana dengan baik. Terimakasih juga penulis haturkan kepada Polteknik Negeri Batam atas pemberian kesempatan bagi penulis untuk melaksanakan kegiatan penelitian serta team yang telah bekeja untuk mensukseskan acara terebut. 


\section{DAFTAR PUSTAKA}

[1] P. V. Latief, B. H. Iskandar, F. Purwangka, M. Program, S. Departemen, dan P. Sumberdaya, "IDENTIFIKASI KESELAMATAN KERJA PADA PROSES PEMBUATAN PERAHU An Identification on Ocupational Safety in A Fiberglass Boat Building Process Oleh :," vol. II, no. 1, hal. 123-133, 2018.

[2] F. Ship, "Studi standardisasi konstruksi laminasi lambung kapal," vol. 13, no. 1, hal. 16-25, 2011.

[3] J. Koto, "Traditional Ship Production."

[4] I. Sahroni et al., "Alat penangkap bau dan uap bahan kimia berbahaya untuk melindungi pekerja kerajinan fiberglass di prambanan diy,” 2013.

[5] A. Wahidin, B. Herijono, dan D. E. Witjonarko, "Edukasi dan Pelatihan Mengenai Repair Perahu Kayu," vol. 1509, hal. 197-200, 2017.

[6] U. Brawijaya dan J. Timur, “Di Kecamatan Lekok, Kabupaten Pasuruan, Jawa Timur,” hal. 3-7.

[7] T. Informatika, F. Teknik, dan U. M. Jakarta, "PENERAPAN METODE ANALYTICAL

HIERARCHY PROCESS ( AHP ) PADA APLIKASI PENDUKUNG KEPUTUSAN SELEKSI KARYAWAN UNICHARM INDONESIA,” vol. 6. 


\section{Lampiran}

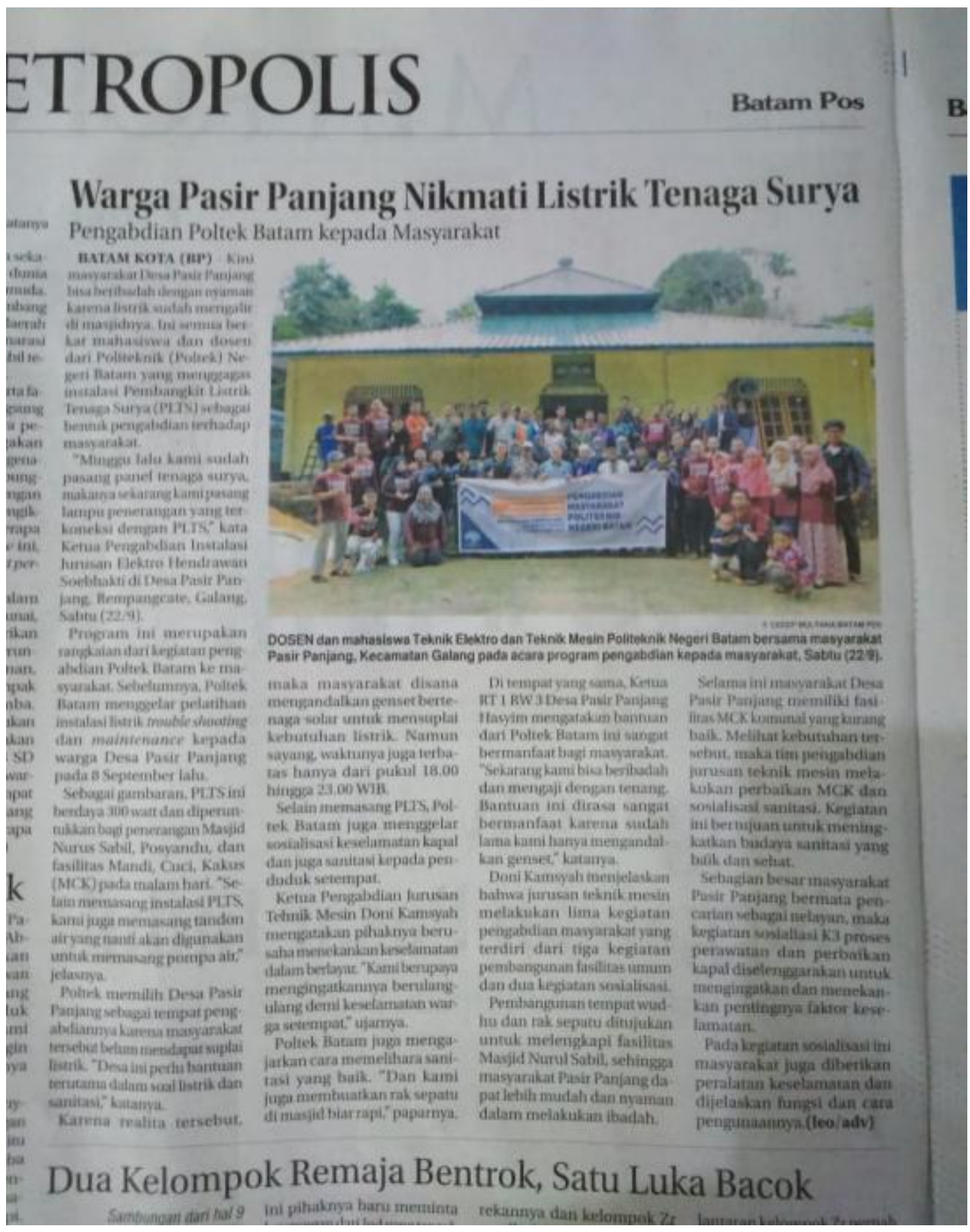

Publikasi Kegiatan Pengabdian Masyarakat 